\title{
CELLULAR AUTOMATA SIMULATION OF THE DYNAMIC RECRYSTALLIZATION OF THE TC4 ALLOY DURING HOT COMPRESSION
}

\author{
SIMULACIJA DINAMIČNE REKRISTALIZACIJE ZLITINE TC4 \\ MED VROČIM STISKANJEM NA OSNOVI CELIČNIH \\ AVTOMATOV
}

\author{
Fei Han ${ }^{1 *}$, Yun Wang ${ }^{1}$, Rongquan Chen ${ }^{1}$, Qi Gao ${ }^{2}$, Yongqiang Wang ${ }^{2}$ \\ ${ }^{1}$ School of Mechanical and Materials Engineering, North China University of Technology, No. 5 Jinyuanzhuang Road, \\ Shijingshan District, Beijing 100144, China \\ ${ }^{2}$ Baoti Group Ltd, No. 88 Gaoxin Avenue, Baoji City, Shaanxi Province 721014, China
}

Prejem rokopisa - received: 2018-12-14; sprejem za objavo - accepted for publication: 2019-04-24

\author{
doi: $10.17222 / \mathrm{mit} .2018 .273$
}

\begin{abstract}
To predict and control the microstructure evolution of the TC4 alloy during hot-compression deformation, a cellular automaton model including dynamic recrystallization (DRX-CA) was established based on dislocation-driven nucleation conditions and the grain-growth dynamics theory. The isothermal compression tests were conducted at temperatures ranging from $1000{ }^{\circ} \mathrm{C}$ to $1200{ }^{\circ} \mathrm{C}$ at $100{ }^{\circ} \mathrm{C}$ intervals and at strain rates ranging from $0.1 \mathrm{~s}^{-1}$ to $10.0 \mathrm{~s}^{-1}$. The effects of the deformation process parameters (strain rate, deformation temperature and deformation degree) on the simulation results were analyzed, including the dynamic recrystallization fraction, average grain size and flow stress curve. Visual simulation of the dynamic recrystallization microstructure evolution of TC4 titanium alloy during high-temperature deformation was completed. For a single-phase area, the simulated flow stress curve was compared with the experimentally obtained stress curve, which verified the rationality and accuracy of the DRX-CA model.
\end{abstract}

Keywords: cellular automata, microstructural evolution, dynamic recrystallization, flow stress

Avtorji prispevka so za napoved in kontrolo razvoja mikrostrukture titanove (Ti) zlitine vrste TC4 med vročo tlačno deformacijo, postavili simulacijski model na osnovi celičnih avtomatov. Ta vključuje dinamično rekristalizacijo (DRX-CA), ki temelji na $\mathrm{z}$ dislokacijami gnanih pogojih nukleacije in teoriji dinamike rasti zrn. Izvajali so izotermne tlačne preizkuse $\mathrm{V}$ temperaturnem območju med $1000{ }^{\circ} \mathrm{C}$ in $1200{ }^{\circ} \mathrm{C}$ v intervalih po $100{ }^{\circ} \mathrm{C}$ in hitrostih deformacije od $(0,1 \mathrm{do} 10,0) \mathrm{s}^{-1}$. Analizirali so vpliv deformacijskih procesnih parametrov (stopnja, hitrost in temperatura deformacije) na rezultate simulacij, vključujoč deleže dinamične rekristalizacije, povprečno velikost kristalnih zrn in krivulje tečenja. Izdelali so vizualno simulacijo dinamične rekristalizacije razvoja mikrostrukture Ti zlitine TC4 med visokotemperaturno deformacijo. Za posamezno fazno področje so s simulacijami dobljene krivulje tečenja primerjali z eksperimentalno dobljenimi, kar je potrdilo racionalnost in natančnost postavljenega DRX-CA modela.

Ključne besede: celični avtomati, razvoj mikrostrukture, dinamična rekristalizacija, napetost tečenja

\section{INTRODUCTION}

The TC4 alloy is a typical titanium alloy and has many attractive properties, such as low density, high specific strength, high temperature resistance and high oxidation and corrosion resistance. These excellent properties have allowed the TC4 alloy to be widely used in aerospace, aviation, navigation, automobile and other industries. ${ }^{1-3}$ Normally, the manufacture of components, for example, forging, punching and cutting, has specific precise requirements on the mechanical and physical properties. In addition, F. Ren et al. ${ }^{4}$ confirmed that the microstructure evolution of the alloy during hot deformation plays a key role in improving the mechanical properties. As known, the flow behavior of materials at elevated temperatures is a source of essential information, X. Shang et al. ${ }^{5}$ and B. Li et al. ${ }^{6}$ have shown that the

*Corresponding author's e-mail:

hanfei@ncut.edu.cn microstructure evolution during hot deformation is very complicated and affected by a multi-physical mechanism, such as work hardening, dynamic recovery and dynamic recrystallization softening and so on. In a macro view, the flow stress changes with the process parameters, such as the temperature, strain rate and deformation extent. In recent years, how to control the microstructure and mechanical properties of products by controlling the temperature, strain rate and deformation degree in hot forming has become a research hotspot in thermoforming. F. Chen et al. $^{7}$ found that dynamic recrystallization (DRX) is one of the most important restoration mechanisms during hot deformation, affecting the final microstructure; therefore, DRX has been increasingly used in the control of the microstructure evolution to obtain finer grains. K. Tan et al. ${ }^{8}$ proposed that the recrystallization behavior of a titanium alloy during hot deformation is an important influencing factor that determines the microstructure and properties. The 
recrystallization evolution of steel has been the subject of extensive previous research and a mathematical model for predicting the microstructure and properties has been established. However, quantitative research on the recrystallization behavior of a titanium alloy during hot deformation has received much less attention.

A finite-element simulation is an economical and effective tool to simulate the material flow behavior and optimize the forming parameters of the material. In a finite-element simulation, the constitutive equation that describes the correlation of the flow stress with the processing parameters is necessary to predict the dynamic flow behavior and optimize the deformation process of metallic materials. ${ }^{9-12}$ In recent years, D. K. Kim et al., ${ }^{13}$ Y. Zhi et al. ${ }^{14}$ and M. H. Pourian et al. ${ }^{15}$ have shown that grain (CA) simulation, which takes into account the curvature of the driving simulation, the stored energy drive of grain-boundary migration, recrystallization and the mesoscopic grain growth behavior, has been applied to materials research; the prediction of the microstructure evolution of metals using CA has become a hot issue in international frontier research. Therefore, the development of a method to predict the evolution of the recrystallization of a titanium alloy during hot deformation is of great significance. In this paper, the combination methods of the principles of physical metallurgy and CA were adopted, and programming was carried out on the platform of MATLAB. The DRX process of the hot compression of the TC4 alloy is predicted.

In the present work, a series of hot-compression tests were performed on the TC4 alloy in the temperature range $1000{ }^{\circ} \mathrm{C}$ to $1200{ }^{\circ} \mathrm{C}$ and strain rate range of $0.1 \mathrm{~s}^{-1}$ to $10.0 \mathrm{~s}^{-1}$. At the same time, a cellular automaton model including dynamic recrystallization (DRX-CA) was established based on dislocation-driven nucleation conditions and the grain-growth dynamics theory. A visual simulation of the dynamic recrystallization microstructure evolution of the TC4 titanium alloy during high-temperature deformation was completed. Then, a series of simulations for the DRX evolution in compressions under different deformation conditions were performed. The effects of the deformation process parameters (strain rate, deformation temperature and deformation degree) on the simulation results were analyzed, including the dynamic recrystallization fraction, average grain size and flow stress curve. For the single-phase region, the simulation results were compared with the flow stress curves to verify the accuracy of the DRX-CA model.

\section{EXPERIMENTAL PART}

The material used in this study is the TC4 alloy. The chemical compositions are given in Table 1. Specimens with a diameter of $10 \mathrm{~mm}$ and a height of $15 \mathrm{~mm}$ were machined from the ingot. The following experimental procedures were conducted according to ASTM:
E209-00. In this study, the processing route for the isothermal hot compression test is simplified as shown in Figure 1. First, the specimens were heated to the pre-set temperature at a heating rate of $10{ }^{\circ} \mathrm{C} / \mathrm{s}$ and held for $300 \mathrm{~s}$ to ensure a uniform temperature field and decrease the material anisotropy. Subsequently, the isothermal compressions were conducted on a computer-controlled, servo-hydraulic Gleeble-3800 simulator. The deformation degree was $60 \%$ for all the specimens. Then, the tests were performed at $1000{ }^{\circ} \mathrm{C}, 1100{ }^{\circ} \mathrm{C}$, and $1200{ }^{\circ} \mathrm{C}$ with strain rates of $0.1 \mathrm{~s}^{-1}, 1.0 \mathrm{~s}^{-1}$ and $10.0 \mathrm{~s}^{-1}$, respectively. To minimize the friction, tantalum foils with a thickness of $0.2 \mathrm{~mm}$ were set between the specimen and the anvils. During the compression process, the variations of the stress and strain were monitored continuously using a personal computer equipped with an automatic data-acquisition system. The true stress and true strain were derived from the measurement of the nominal stress-strain relationship. The true stress-strain curves were recorded automatically in the isothermal compression process.

Table 1: Chemical composition of TC4 alloy ( $w / \%)$

\begin{tabular}{|c|c|c|c|c|c|c|c|}
\hline $\mathrm{Al}$ & $\mathrm{V}$ & $\mathrm{Fe}$ & $\mathrm{O}$ & $\mathrm{N}$ & $\mathrm{C}$ & $\mathrm{H}$ & $\mathrm{Ti}$ \\
\hline 6.02 & 3.78 & 0.052 & 0.18 & 0.0062 & 0.008 & 0.0049 & Balance \\
\hline
\end{tabular}

\section{METHODOLOGY}

\subsection{Calculation of the activation energy for hot defor- mation}

M. H. Wang et al. ${ }^{16}$ have shown that the activation energy derived by constitutive analyses is normally used as an indicator to evaluate the difficulty of the hot-deformation process. It can also furnish information about the microstructure and flow stress evolution in successive deformation processes to determine the deformation mechanism. During hot deformation, the potential for atomic diffusion and the driving force for dislocation movement depend on the deformation temperature. The growth velocity of the dislocation densities and the grain-boundary energy depend on the strain rate.



Figure 1: Experiment on high temperature compression 
Therefore, the peak stress has conventionally been considered to depend on the deformation temperature and strain rate. Based on the above statements, the following constitutive model was proposed by J. J. Sellars and C. M. Tegart ${ }^{17}$ to calculate the activation energy for hot deformation.

$$
\dot{\varepsilon}=A F(\sigma) \exp \left(-\frac{Q}{R T}\right)
$$

where $F(\sigma)$ is a function of the flow stress. The function has three forms depending on the flow-stress level. Under low-stress conditions, the relationship between the flow stress and strain rate can be expressed as:

$$
\dot{\varepsilon}=A_{1} \sigma^{n_{1}} \exp \left(-\frac{Q}{R T}\right) \quad \alpha \sigma<0.8
$$

Under high-stress conditions, this relationship can be expressed as:

$$
\dot{\varepsilon}=A_{2} \exp (\beta \sigma) \exp \left(-\frac{Q}{R T}\right) \quad \alpha \sigma<1.2
$$

At any other stress level, this relationship can be expressed as:

$$
\dot{\varepsilon}=A[\sinh (\alpha \sigma)]^{n} \exp \left(-\frac{Q}{R T}\right)
$$

The deformation activation energy is calculated by Equation (5):

$$
Q=\left.\left.R \cdot \frac{\partial \ln \dot{\varepsilon}}{\partial \ln [\sinh (\alpha \sigma)]}\right|_{T} \cdot \frac{d\{l \ln [\sinh (\alpha \sigma)]\}}{d(1 / T)}\right|_{\varepsilon}
$$

where $A, A_{1}$, and $A_{2}$ are material constants; $n$ and $n_{1}$ are the stress exponents; $\alpha$ and $\beta$ are the stress level parameters $(\alpha=\beta / n)$; and $R$ is the molar gas constant $(\mathrm{J} / \mathrm{mol} \cdot \mathrm{K}) . T$ is the absolute deformation temperature $(\mathrm{K}) ; Q$ is the deformation activation energy $(\mathrm{kJ} / \mathrm{mol})$, which shows how easily the material is hot deformed; $\dot{\varepsilon}$ is the strain rate $\left(\mathrm{s}^{-1}\right)$; and $\sigma$ is the flow stress $(\mathrm{MPa})$ for a given strain. According to the above formulas, the deformation activation energy $Q$ is $199.967 \mathrm{~kJ} / \mathrm{mol}$.

\subsection{Theoretical model for DRX}

Dynamic recrystallization (DRX) occurs only when the dislocation density in a deforming matrix accumulates to a critical level or the strain reaches a critical value. The two important aspects of DRX that affect the microstructure are nucleation and grain growth, and both are closely related to the dislocation density. Therefore, three theory models have been proposed by researchers to characterize the microstructure evolution of the TC4 alloy during hot deformation. H. Kocks and U. F. Mecking ${ }^{18}$ developed the KM model to predict the variation of the dislocation density. The model assumes that the flow stress of the high-temperature plastic deformation of the material is determined by dislocation density. The relationship between dislocation density and strain is as follows:

$$
\frac{\mathrm{d} \rho}{\mathrm{d} \varepsilon}=k_{1} \sqrt{\rho}-k_{2} \rho
$$

Based on the assumption of the KM model, the dislocation density increases with the increase of strain. It is generally considered that the flow stress is proportional to the square root of the average dislocation density. The expression is as follows:

$$
\begin{gathered}
\sigma=\frac{1}{2} \mu b \sqrt{\rho} \\
\mu=\mu_{0}\left(1-0.91 \frac{T-300}{T_{\mathrm{m}}}\right)
\end{gathered}
$$

where $k_{1}$ is the work-hardening coefficient and $k_{2}$ is the softening coefficient. $\bar{\rho}$ is the average dislocation density, $b$ is the Burgers vector and $\mu$ is the shear modulus. $\mu_{0}$ is the shear modulus corresponding to the material at room temperature $(300 \mathrm{~K}) . T_{m}$ is the melting point.

The average dislocation density $\bar{\rho}$ in a particular region at different times is determined by the average of the dislocation densities of all the cells in the region:

$$
\rho=\frac{1}{N_{0}} \sum_{i, j}^{i=A, j=B} \rho_{i, j}
$$

where $N_{0}$ is the total number of cells in the CA simulation region, i.e., $N_{0}=A \times B ; A$ and $B$ represent respectively the number of cells in the $i, j$ direction; $\rho_{i, j}$ is the dislocations density of the cells at coordinates $(i, j)$.

Z. X. Guo and R. Ding ${ }^{19,20}$ developed the nucleation model to calculate the nucleation rate of DRX. The model considers the relationship between the nucleation rate, temperature and strain rate, which can be expressed as:

$$
\dot{n}(\dot{\varepsilon}, T)=C \dot{\varepsilon} \exp \left(-\frac{Q_{\text {nucl }}}{R T}\right)
$$

where $C$ is the material constant, $\dot{\varepsilon}$ is strain rate, $Q_{\text {nucl }}$ is the activation energy for nucleation $(\mathrm{kJ} / \mathrm{mol})$.

Dynamic recrystallization nucleation occurs when the dislocation density reaches the critical dislocation density of dynamic recrystallization during thermal processing. The critical dislocation density $\rho_{\mathrm{c}}$ can be calculated from the energy required for grain nucleation.

$$
\begin{gathered}
\rho_{\mathrm{c}}=\left(\frac{20 \gamma_{\mathrm{m}} \dot{\varepsilon}}{3 b l M \tau^{2}}\right) \\
M=\frac{\delta D_{\mathrm{ob}} b}{k T} \exp \left(-\frac{Q_{\mathrm{b}}}{R T}\right) \\
\tau=\frac{1}{2} \mu b^{2} \\
l=\frac{10 \mu b}{\delta_{\mathrm{s}}}
\end{gathered}
$$


where $\gamma_{\mathrm{m}}$ is the grain-boundary energy of the high-angle boundary, $M$ is the mobility of the grain boundary, $\tau$ the line energy, $l$ is the average free distance of dislocation. $\delta$ is the thickness of the characteristic boundary, $D_{\mathrm{ob}}$ is the diffusion coefficient at $0 \mathrm{~K}, k$ is the Boltzmann constant, $Q_{\mathrm{b}}$ is the self-diffusion activation energy. $\delta_{\mathrm{s}}$ is the saturated flow stress, which can be obtained from the true stress-strain curve.

R. Roberts and B. Ahlblom ${ }^{21}$ developed the graingrowth kinetics model to determine the link between the driving force and the stored strain-energy difference between the dynamic recrystallized grains and the matrix. After dynamic recrystallization nucleation, the essence of recrystallized grain growth is the migration of highangle grain boundaries. The growth rate of a new grain can be expressed as:

$$
\begin{gathered}
V_{i}=M f_{i} \\
f_{i}=\tau\left(\rho_{\mathrm{m}}-\rho_{i}\right)-2 \frac{\gamma_{i}}{r_{i}} \\
\gamma_{i}=\left\{\begin{array}{c}
\theta_{i} \geq 15^{\circ} \mathrm{C} \\
\gamma_{\mathrm{m}} \frac{\theta_{i}}{\theta_{\mathrm{m}}}\left(1-\ln \frac{\theta_{i}}{\theta_{\mathrm{m}}}\right] \quad \theta_{i} \leq 15^{\circ} \mathrm{C}
\end{array}\right.
\end{gathered}
$$

where $\rho_{\mathrm{m}}$ and $\rho_{i}$ are the dislocation density in the original and recrystallized grains, respectively, $\gamma_{\mathrm{m}}$ is the interface energy of the $i^{\text {th }}$ grain, $r_{i}$ is the $i^{\text {th }}$ recrystallized grain radius, $\theta_{m}$ is the misorientation angle when the grain boundary becomes a high-angle boundary (in this study $\left.\theta_{\mathrm{m}}=15^{\circ}\right), \theta_{i}$ is the grain boundary between the $i^{\text {th }}$ grain and its neighboring grain.

These values of the material constants used in this study are listed in Table 2.

Table 2: Material parameters of TC4 alloy

\begin{tabular}{|c|c|c|c|}
\hline$b(\mathrm{~nm})$ & $\mu(\mathrm{GPa})$ & $Q_{\mathrm{b}}(\mathrm{KJ} / \mathrm{mol})$ & $Q_{\text {nucl }}(\mathrm{KJ} / \mathrm{mol})$ \\
\hline
\end{tabular}

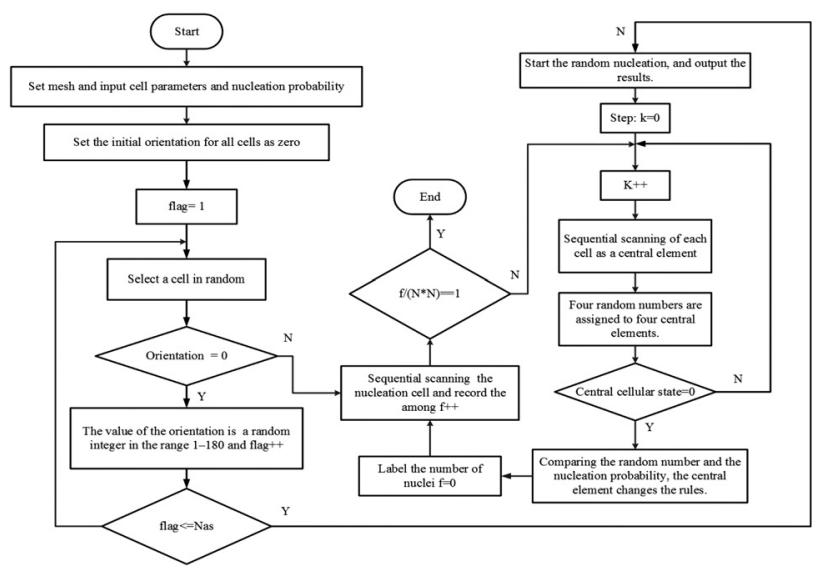

Figure 2: Programming flowchart for achieving the initial microstructure with DRX-CA

\begin{tabular}{|c|c|c|c|}
\hline 0.286 & 21.93 & 120 & 199.967 \\
\hline$\theta_{\mathrm{m}}\left(^{\circ}\right)$ & $\delta D_{\mathrm{ob}}$ & $T_{\mathrm{m}}(\mathrm{K})$ & \\
\hline 15 & $5.4^{*} 10^{-17}$ & 1933 & \\
\hline
\end{tabular}

\subsection{Cellular automata model for DRX}

Based on the theory model of DRX, combined with the CA method, the DRX model for the TC4 alloy during hot compressive deformation was developed with two major steps. The first step was to create the initial microstructure via a normal grain-growth algorithm, and the flowchart is shown in Figure 2.

First, the cellular orientation variable in the entire simulation area is initialized to zero, and the number of nucleation of dynamic recrystallization is set. Cells are randomly selected at any position in the simulation region, and if the cellular orientation variable is zero, a random integer is assigned between cells 1 to 180 . Conversely, if the cellular orientation variable is not zero, the cells at any position are reselected until the number of dynamically recrystallized cells reaches the specified number of nucleation. With the nucleation point as the center, the periodic boundary conditions for growth are adopted, and the entire simulated area is scanned. Four random numbers are generated that correspond to the four neighbouring cells of the central cell, and four random numbers are compared with the nucleation probability. The central cell is transformed according to the rules, and the initial tissue morphology is displayed by using the MATLAB image-display function.

The CA simulation process of the dynamic recrystallization process of the TC4 titanium alloy is shown in Figure 3. The detailed steps for the CA model are as follows:

1) Initial microstructure created in the first step;

2) Input material and process parameters;

3) Set the calculation time and steps of the model;

4) Calculate dislocation density;

5) Nucleation of recrystallization;

6) Grain growth of recrystallization.

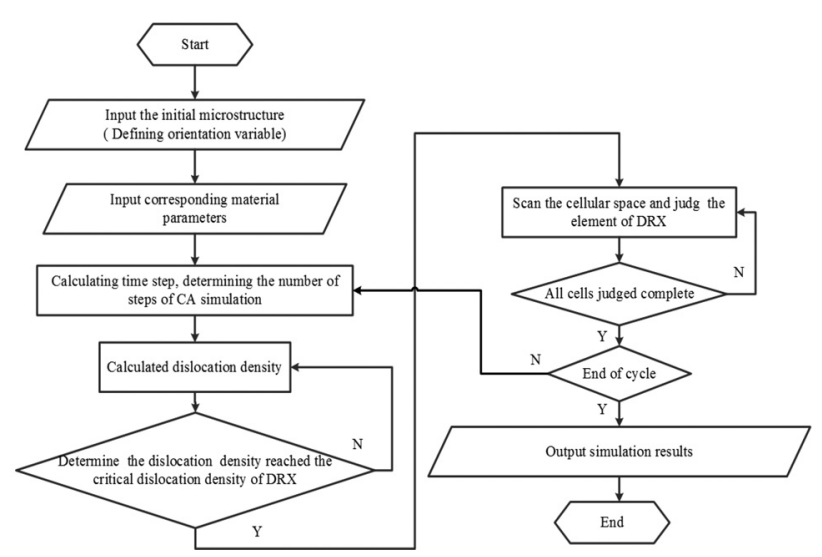

Figure 3: Programming flowchart of the microstructure evolution simulation with DRX-CA 


\section{RESULTS AND DISCUSSION}

\subsection{Hot-deformation flow curves}

The true stress-strain curves obtained from the hot compression tests at different deformation temperatures and strain rates are shown in Figure 4. These curves show the flow stress change with different process parameters such as temperature, strain rate and deformation extent. It was obvious that the flow curves with different deformation temperatures and strain rates had a similar variation. That is, the flow stress increased quickly with the increase in strain at the beginning. The increase
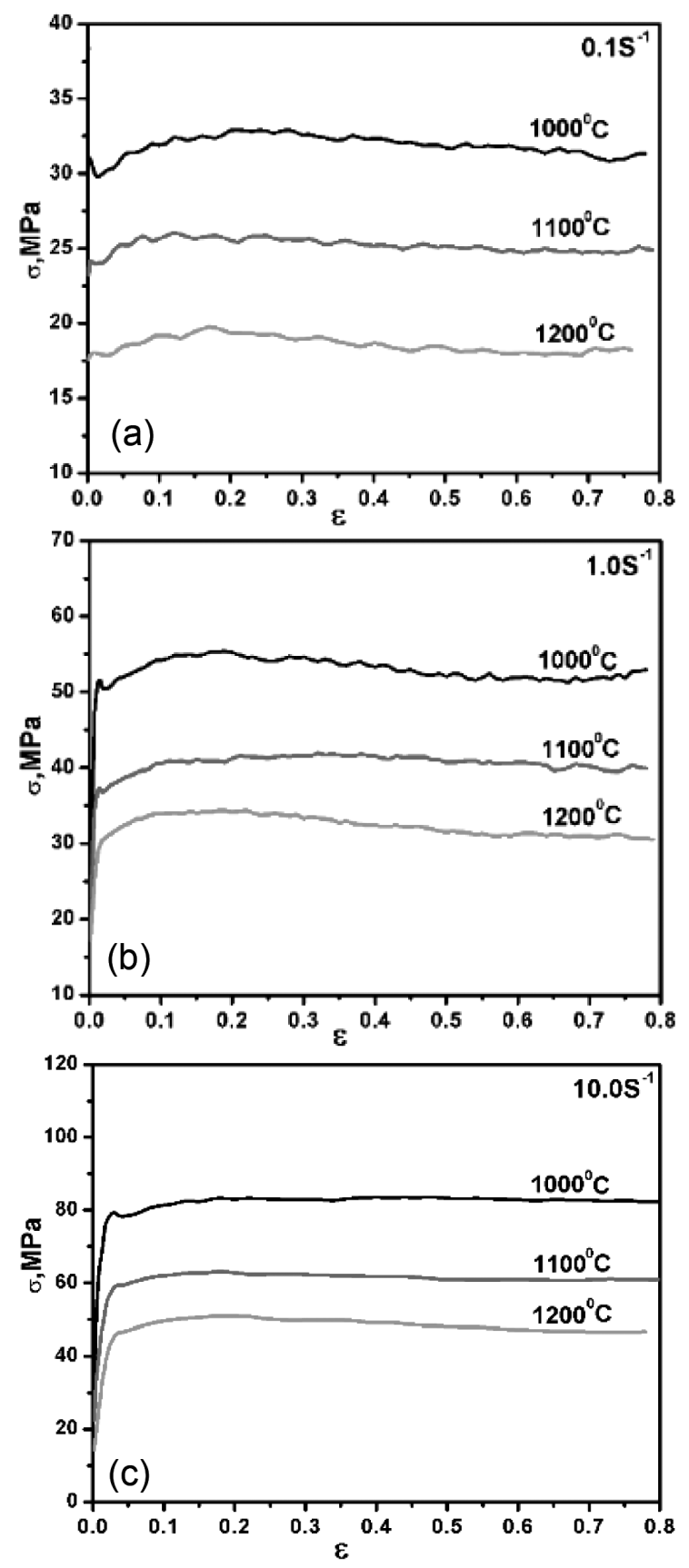

Figure 4: Flow stress curves of TC4 alloy at different strain rates occurs because in this stage, the generation and multiplication of dislocations that induce working hard (WH) develop rapidly. Meanwhile, the accompanying dynamic recovery (DRV) caused by the annihilation of dislocations due to the ease of cross slip, climb, and dislocation unpinning at the hot-working temperatures is too weak to overcome WH. Then, a rising trend is maintained until the flow pressure peak is reached. Finally, the flow stress maintains a stable value and does not change with the increase in strain. At this stage, another softening mechanism, i.e., DRX, takes place, resulting in the gradual decrease in the work-hardening rate with the increase in the strain. When the dynamic softening (DRV and DRX) rate is equal to the work hardening rate, the flow stress reaches a peak value, following which the flow stress gradually decreases due to the predominant softening mechanism, i.e., DRX, until a steady stage.

Under the condition of the same strain rate, the flow stress decreases with the increase in deformation temperature. However, under the condition of the same deformation temperature, the flow stress increases with the increase of the strain rate. According to M. S. Chen et al. ${ }^{22}$ and A. Mohamadizadeh et al., ${ }^{23}$ this is mainly because a lower strain rate provides a longer time for energy accumulation and that a higher deformation temperature promotes the mobility at the boundaries for the annihilation of dislocations and the nucleation and growth of dynamically recrystallized grains, thus reducing the flow stress level.

\subsection{Initial microstructures}

In this study, the microstructural evolution of a TC4 alloy during DRX was simulated at various strain rates and temperatures. The simulation lattice was set at $400 \times 400$, and periodic boundary conditions were used. The size of one lattice represents $4 \mu \mathrm{m}$ of the real dimension of the material, and hence the simulation area corresponds to $1600 \mu \mathrm{m} \times 1600 \mu \mathrm{m}$ in a real sample. The initial microstructure for the TC4 alloy is shown in Figure 5. From the final initial microstructure simulation



Figure 5: The initial microstructure of the TC4 alloy before CA simulation 
diagram, we can see that most of the grains are hexagonal in shape, and basically all the intersections are trilateral intersections. The angle is approximately $120^{\circ}$.

Moreover, the growth of the crystal grains is mainly achieved by continuously phagocytizing small crystal grains by large crystal grains. Through the change in the grain topological structure, the initial structure of grain coarsening and growth is completed. According to the above principle, a single-phase microstructure, i.e., a cellular automaton simulation of the $\beta$ phase, is constructed.

\subsection{The effect of strain rate on DRX}

Under the specified conditions, the simulation of the microstructure evolution of the TC alloy during DRX at a deformation temperature of $1000{ }^{\circ} \mathrm{C}$ and strain rates of $0.1 \mathrm{~s}^{-1}$ and $1.0 \mathrm{~s}^{-1}$ was conducted, and the results are shown in Figure 6. The effect of different strain rates on the volume fraction recrystallization is shown in Figure 7. The corresponding recrystallization volume fractions are $4.42 \%$ and $2.29 \%$, respectively, and the recrystallized average grain sizes are $3.0 \mu \mathrm{m}$ and $2.47 \mu \mathrm{m}$.

These results show that the time to reach the required deformation degree is shorter with the increase in strain rate, and the proportion of dynamic recrystallization is less. This is because the driving force for recrystallization is generally provided by the storage energy of the metal. When the strain rate is low, the storage energy in the alloy is less, which reduces the driving force of the recrystallization. Therefore, the volume fraction of the dynamic recrystallization decreases with the increase in strain rate. At the same time, as the strain rate increases, the relative time that recrystallization occurs is later, and the recrystallization does not occur sufficiently, which makes the recrystallized grain not grow sufficiently in the growth cycle, and the dislocation density is increasing. Therefore, the grain size of the dynamic recrystallization decreases with the increase of strain rate, i.e., finer recrystallization grains can be obtained at a higher strain rate, but the proportion of recrystallization that occurs is lower. A lower strain rate is favorable for the occurrence of dynamic recrystallization, but the microstructure of the recrystallized grains is coarser. These

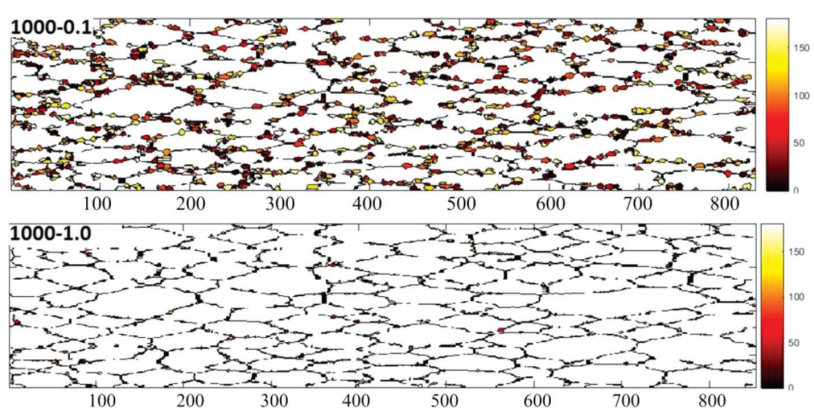

Figure 6: The effects of strain rate variation on the microstructure at $T=1000^{\circ} \mathrm{C}$

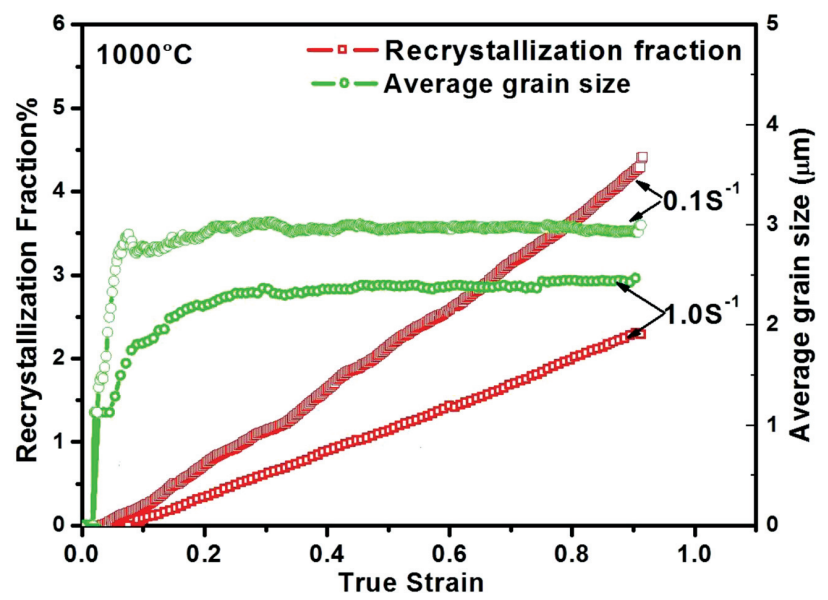

Figure 7: The effect of strain rate on the volume fraction recrystallization and recrystallized grain size

laws are consistent with the experiments, which fully verify the correctness of the model.

\subsection{The effect of temperature on DRX}

The CA simulations of the microstructure evolution of the TC4 alloy during DRX at a strain rate of $1.0 \mathrm{~s}^{-1}$ and two temperatures of $1000{ }^{\circ} \mathrm{C}$ and $1100{ }^{\circ} \mathrm{C}$ were conducted, and the numerical results are shown in Figure 8. The effect of different temperatures on the volume fraction recrystallization can be found in Figure 9. The corresponding recrystallization volume fractions are $2.29 \%$ and $6.78 \%$, respectively, and the recrystallized average grain size are $2.47 \mu \mathrm{m}$ and $3.64 \mu \mathrm{m}$.

The results show that when the strain rate is constant, the dynamic recrystallization percentage and the average size of the dynamic recrystallized grains gradually increase with the increase in the deformation temperature. The higher the temperature is, the more new recrystallized nuclei are formed and the migration rate of grain boundaries is much higher. That is, the more favorable the nucleation and grain growth of the recrystallization. However, too high of a temperature will make the microstructure of the recrystallized grains become coarse. Generally, when the strain is the same, the higher the deformation temperature or the lower the strain rate is, the easier the dynamic recrystallization can occur, and


Figure 8: The effects of temperature variation on the microstructure at $\dot{\varepsilon}=1.0 \mathrm{~s}^{-1}$ 


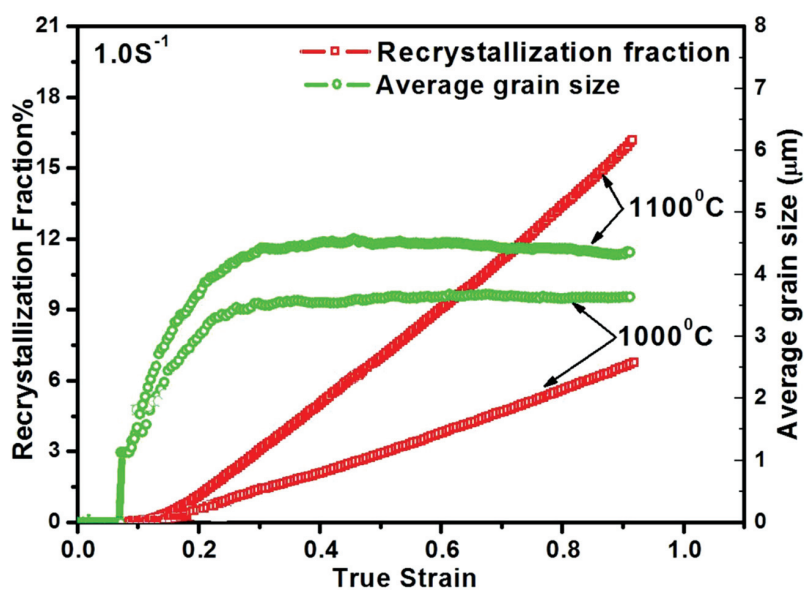

Figure 9: The effect of temperature on the volume fraction recrystallization and recrystallized grain size

the higher the dynamic recrystallization percentage. Dynamic recrystallization always occurs when the strain reaches a certain critical value at a given strain rate and deformation temperature. When the deformation temperature is constant, the higher the strain rate is, the greater the critical strain value at which dynamic
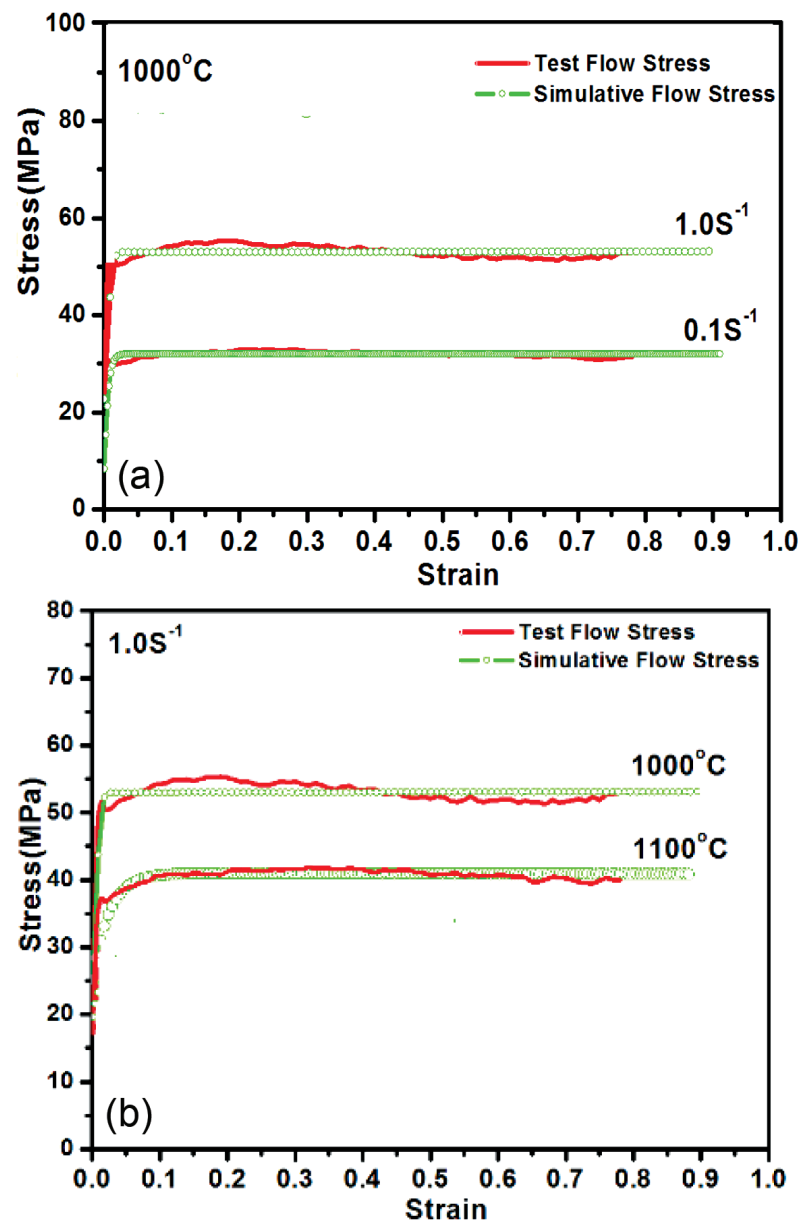

Figure 10: Comparison of the flow stress curves between the test and simulation recrystallization occurs. When the strain rate is constant, the higher the temperature is, the smaller the critical strain value of the dynamic recrystallization.

\subsection{The comparison of flow stress curve}

To further verify the accuracy of the model, a comparison of the flow stress curves of the TC4 alloy during hot deformation from the experiment and the CA simulation is shown in Figure 10. And because the temperature is above the phase transition point, the TC4 alloy is in the $\beta$ phase region. The results show that the variation of the flow stress curve obtained by using the cellular automaton model at different deformation temperatures is in good agreement with the flow stress curve obtained by the thermal compression test, with the typical characteristics of dynamic recovery rheological curves.

Moreover, the simulated steady flow stress and peak flow stress are slightly larger than the actual experimental results. The main reason for this result is that the DRX-CA model has assumptions and simplifications that do not consider the two-phase particles and other microstructure defects. And the internal dislocation density during the actual material deformation process is difficult to measure, and the dislocation density used in the simulation is slightly different from the dislocation density of the actual material.

\section{CONCLUSIONS}

Based on the dislocation-driven nucleation conditions and grain-growth dynamics theory, a dynamic recrystallization model (DRX-CA) was established to visualize the dynamic recrystallization microstructure evolution of the TC4 titanium alloy during high-temperature deformation. The achievements of the current research are summarized as follows:

1) The initial microstructure of the TC4 titanium alloy and the microstructure change during the dynamic recrystallization of high-temperature compression deformation were simulated by using the established DRX-CA model.

2) The effects of the deformation process parameters (strain rate, deformation temperature and deformation degree) on the simulation results were analyzed, including dynamic recrystallization fraction, average grain size and flow stress curve. The simulation results showed that with the increase in strain, the decrease in strain rate and the increase in deformation temperature, the recrystallization volume fraction and recrystallization average grain size steadily increased.

3) For a single-phase area, the simulated flow stress curve was compared with the experimentally obtained stress curve, which verified the rationality and accuracy of the DRX-CA model. 


\section{REFERENCES}

${ }^{1}$ H. Xin, Y. Y. Shi, Surface Morphology and Affected Layer in Discmilling Grooving of Titanium Alloy, Rare Metal Mat. Eng., 45 (2016) 12, 3050-3056, doi:10.1080/10910344.2017.1284561

${ }^{2}$ X. Wang, L. Wang, L. S. Luo, H. Y. Xin, Z. Li, R. R. Chen, Y. Q. Su, J. J. Guo, H. Z. Fu, High temperature deformation behavior of melt hydrogenated $(\mathrm{TiB}+\mathrm{TiC}) / \mathrm{Ti}-6 \mathrm{Al}-4 \mathrm{~V}$ composites, Mater. Design, 121 (2017), 335-344, doi:10.1016/j.matdes.2017. 02.075

${ }^{3}$ Y. G. Liu, M. Q. Li, H. J. Liu, Surface nanocrystallization and gradient structure developed in the bulk TC4 alloy processed by shot peening, J. Alloy. Compd., 685 (2016), 186-193, doi:10.1016/ j.jallcom.2016.05.295

${ }^{4}$ F. Ren, F. Chen, J. Chen, Investigation on Dynamic Recrystallization Behavior of Martensitic Stainless Steel, Adv. Mater. Sci. Eng., 30 (2014), 1-16, doi:10.1155/2014/986928

${ }^{5}$ X. Shang, A. He, Y. Wang, X. Yang, H. Zhang, X. Wang Flow behavior modeling of a nitrogen-alloyed ultralow carbon stainless steel during hot deformation: A comparative study of constitutive models, J. Mater. Eng. Perform., 24 (2015), 4106-4118, doi:10.1007/ s11665-015-1666-z

${ }^{6}$ B. Li, Q. L. Pan, C. Li, Z. Y. Zhang, Z. M. Yin, Hot compressive deformation behavior and constitutive relationship of Al-Zn-Mg-Zr alloy with trace amounts of Sc, J. Cent. South Univ., 20 (2013) 11, 2939-2946, doi:10.1007/s11771-013-1816-0

${ }^{7}$ F. Chen, K. Qi, Z. S. Cui, X. Lai, Modeling the dynamic recrystallization in austenitic stainless steel using cellular automaton method, Comp. Mater. Sci., 83 (2014) 2, 331-340, doi:10.1016/j.commatsci. 2013.11.029

${ }^{8}$ K. Tan, J. Li, Z. J. Guan, J. Yang, J. Shu, The identification of dynamic recrystallization and constitutive modeling during hot deformation of Ti55511 titanium alloy, Mater. Design, 84 (2015), 204-211, doi:10.1016/j.matdes.2015.06.093

${ }^{9}$ G. Chen, C. Z. Ren, X. Qin, J. Li, Temperature dependent work n hardening in Ti-6Al-4V alloy over large temperature and strain rate ranges: experiments and constitutive modeling, Mater. Design, 83 (2015), 598-610, doi:10.1016/j.matdes.2015.06.048

${ }^{10}$ J. H. Kim, S. L. Semiatin, Y. H. Lee, C. S. Lee, A self-consistent approach for modeling the flow behavior of the alpha and beta phases in Ti-6Al-4V, Metall. Mater. Trans. A Phys. Metall. Mater. Sci., 42 (2011) 7, 1805-1814, doi:10.1007/s11661-010-0567-x

${ }^{11}$ Y. G. Liu, M. Q. Li, J. Luo, The modelling of dynamic recrystallization in the isothermal compression of $300 \mathrm{M}$ steel, Mat. Sci. Eng. A-Struct., 574 (2013) 6, 1-8, doi:10.1016/j.msea.2013.03.011
${ }^{12}$ X. L. Hou, Y. Li, P. v, J. Cai, L. Ji, Q. F. Guan, Hot deformation behavior and microstructure evolution of a $\mathrm{Mg}-\mathrm{Gd}-\mathrm{Nd}-\mathrm{Y}-\mathrm{Zn}$ alloy, Rare Met., 35 (2016) 7, 532-536, doi:10.1007/s12598-015-0507-4

${ }^{13}$ D. K. Kim, W. C. Woo, W. W. Park, Y. T. Im, A. Rollett, Mesoscopic coupled modeling of texture formation during recrystallization considering stored energy decomposition, Comp. Mater. Sci., 129 (2017), 55-65, doi:10.1016/j.commatsci.2016.11.048

${ }^{14}$ Y. Zhi, X. H. Liu, H. L. Yu, Cellular automaton simulation of hot deformation of TRIP steel, Comp. Mater. Sci., 81 (2014), 104-112, doi:10.1016/j.commatsci.2013.05.028

${ }^{15}$ M. H. Pourian, P. Pilvin, F. Bridier, P. Bocher, Modeling the elastoplastic behaviors of alpha Ti-alloys microstructure using Cellular Automaton and finite element methods, Comp. Mater. Sci., 99 (2015), 33-42, doi:10.1016/j.commatsci.2014.11.027

${ }^{16}$ M. H. Wang, K. Wei, X. J. Li, A. Z. Tu, Constitutive modeling for high temperature flow behavior of a high-strength manganese brass, J. Cent. South Univ., 25 (2018) 7, 1560-1572, doi:10.1007/s11771018-3848-y

${ }^{17}$ J. J. Jonas, C. M. Sellars, W. J. M. Tegart, Strength and structure under hot-working conditions, Metall. Rev., 14 (1969) 1, 1-24, doi:10.1179/mtlr.1969.14.1.1

${ }^{18}$ H. Mecking, U. F. Kocks, Kinetics of flow and strain-hardening, Acta Metall., 29 (1981) 11, 1865-1875, doi:10.1016/00016160(81)90112-7

${ }^{19}$ R. Ding, Z. X. Guo, Coupled quantitative simulation of microstructural evolution and plastic flow during dynamic recrystallization, Acta Mat., 49 (2001), 3163-3175, doi:10.1016/s13596454(01)00233-6

${ }^{20}$ R. Ding, Z. X. Guo, Microstructural modelling of dynamic recrystallisation using an extended cellular automaton approach, Comp. Mater. Sci., 23 (2002) 10, 209-218, doi:10.1016/s09270256(01)00211-7

${ }^{21}$ W. Roberts, B. Ahlblom, A nucleation criterion for dynamic recrystallization during hot working, Acta Metall., 26 (1978) 78, 801-813, doi:10.1016/0001-6160(78)90030-5

${ }^{22}$ M. S. Chen, Y. C. Lin, X. S. Ma, The kinetics of dynamic recrystallization of $42 \mathrm{CrMo}$ steel, Mater. Sci. Eng. A, 556 (2012), 260-266, doi:10.1016/j.msea.2012.06.084

${ }^{23}$ A. Mohamadizadeh, A. Zarei-Hanzaki, H. R. Abedi, S. Mehtonen, D. Porter, Hot deformation characterization of duplex low-density steel through 3D processing map development, Mater. Charact., 107 (2015), 293-301, doi:10.1016/j.matchar.2015.07.028 